\title{
Exposure to particulate matter: a brief review with a focus on cardiovascular effects, children, and research conducted in Turkey
}

\author{
Aylin Elkama, Ayça Aktaş Şüküroğlu, and Gonca Çakmak \\ Gazi University Faculty of Pharmacy, Department of Toxicology, Ankara, Turkey
}

[Received in June 2021; Similarity Check in June 2021; Accepted in November 2021]

Exposure to environmental particulate matter (PM), outdoor air pollution in particular, has long been associated with adverse health effects. Today, PM has widely been accepted as a systemic toxicant showing adverse effects beyond the lungs. There are numerous studies, from those in vitro to epidemiological ones, suggesting various direct and indirect PM toxicity mechanisms associated with cardiovascular risks, including inflammatory responses, oxidative stress, changes in blood pressure, autonomic regulation of heart rate, suppression of endothelium-dependent vasodilation, thrombogenesis, myocardial infarction, and fibrinolysis. In addition to these and other health risks, considerations about air quality standards should include individual differences, lifestyle, and vulnerable populations such as children. Urban air pollution has been a major environmental issue for Turkey, and this review will also address current situation, research, and measures taken in our country.

KEY WORDS: air quality; cardiovascular toxicity; monitoring; regulations; vulnerable populations

It is difficult to attribute toxic and health effects of air pollution to one compound alone, since ambient air is a mixture of gases, particles, and liquids that interact with each other and may have synergistic effects. Environmental air pollution and its main component, particulate matter (PM), is an attractive subject of toxicological research ranging from in vitro to molecular epidemiology studies. Epidemiological research has revealed a relationship between PM in ambient air and serious chronic diseases. According to the World Health Organization (WHO), fine PM (of 2.5 microns or less in diameter) accounts for more premature deaths globally than other air pollutants (1). Furthermore, PM as a major constituent of outdoor air pollution has recently been classified as human carcinogen (Group 1) by the International Agency for Research on Cancer (IARC) (2). The detrimental health effects of airborne PM are not limited to respiratory diseases but encompass other systemic diseases, most notably the cardiovascular $(\mathrm{CV})$ ones, including myocardial infarction, hypertension, atherosclerosis, thrombosis, cardiac arrhythmias, and stroke $(3,4)$. In addition, a large body of evidence demonstrates that PM is closely related to diseases in vulnerable populations such as the elderly and children (5).

The aim of this brief review was to sum up current knowledge on global and local exposure to PM in Turkey, its sources, mechanisms of action, and adverse effects on

Corresponding author: Gonca Çakmak, Gazi University Faculty of Pharmacy, Department of Toxicology, 06330, Ankara, Turkey, E-mail: gcakmak@gazi.edu.tr, ORCID: 0000-0002-6283-5404 the CV system, especially in children. It will also address how regulatory and personal intervention can reduce health risks and what has been done in Turkey in this respect.

\section{WHAT IS PARTICULATE MATTER?}

Particular matter is not a specific pollutant but a complex mixture of solid particles and liquid droplets (dust, dirt, soot, or smoke) of organic and inorganic substances suspended in the air (6). By size PM is divided into three main categories: coarse, fine, and ultrafine. Coarse particles $\left(\mathrm{PM}_{10}\right)$ have the aerodynamic diameter from 2.5 to $10 \mu \mathrm{m}$ and are mostly composed of dust raised from disturbed soil and surfaces. Its major sources are industry and traffic, most notably mining, farming, unpaved roads, plant and animal fragments, and building construction (7). Fine and ultrafine particles are those with an aerodynamic diameter of $<2.5 \mu \mathrm{m}\left(\mathrm{PM}_{2.5}\right)$ and $<0.1 \mu \mathrm{m}\left(\mathrm{PM}_{0.1}\right)(8)$, respectively, and are mostly composed of organic matter (9). Fine PM is mostly anthropogenic, generated by fossil fuel combustion (e.g. power plants), residential heating, and automobile exhausts (diesel engine emissions, in particular) (7). Ultrafine particles come from natural and anthropogenic sources and precursor gases (10). As far as the particle size is concerned it overlaps with nanoparticles (NPs), which may also be associated with CV diseases (11). However, NPs are manufactured (for a variety of purposes) and not the consequence of emissions, which is why we shall focus on ambient (air-suspended) particles alone. 
Physical and chemical properties of PM relevant for health outcomes depend on many parameters besides size, including PM components, season, meteorological conditions, industrial and combustion sources, and traffic intensity $(12,13)$. Depending on emission source, the carbonaceous core of PM can have organic and inorganic compounds (e.g. transition metals, polycyclic aromatic- and nitro-hydrocarbons, acid aerosols) attached, whose composition determines its toxicity and associated health outcomes (14), while size determines its penetration capability in the organism (15).

\section{CARDIOVASCULAR OUTCOMES OF PARTICULATE MATTER: LESSONS LEARNED FROM EPIDEMIOLOGY STUDIES}

By some accounts, air pollution is responsible for $19 \%$ of all deaths caused by CV diseases and for $21 \%$ of all deaths caused by stroke (16). According to a recent Global Exposure Mortality Model based on cohort studies in Europe [including 28 European Union (EU) countries], annual excess mortality rate from ambient air pollution is estimated to 790,000 , and $40-80 \%$ of this excess mortality is owed to CV events (17). A study in a Danish cohort of 49,564 people found increased risk of CV disease mortality from exposure to $\mathrm{PM}_{2.5}$, black carbon, and nitrogen dioxide $\left(\mathrm{NO}_{2}\right)(18)$. One Chinese study, in turn, showed that $\mathrm{PM}_{10}$ and sulphur dioxide $\left(\mathrm{SO}_{2}\right)$ were associated with higher $\mathrm{CV}$ disease mortality (19). In Iran higher relative risk of CV disease mortality was associated with exposure to PM $(6.6 \%)$ and ozone $\left(\mathrm{O}_{3}\right)(2 \%)(20)$.

Clearly, combined exposure to toxic compounds within $\mathrm{PM}$ and other common air pollutants such as $\mathrm{SO}_{2}, \mathrm{NO}_{2}$, and $\mathrm{O}_{3}$ is expected to exacerbate CV problems (21), yet, cardiovascular toxicity from exposure to combinations of air pollutants is poorly understood, and health effects are usually evaluated for each component alone (22). Given that combined exposure is difficult to evaluate, the last few decades of research have seen a shift of focus toward the relationship between PM size and systemic effects beyond respiratory, such as cardiovascular and neurological $(3,22)$.

\section{PM sources and size as determinants of cardiovascular toxicity}

Short and long-term exposure to $\mathrm{PM}_{10}$ and $\mathrm{PM}_{25}$ is a major contributor to $\mathrm{CV}$ toxicity. In fact, $\mathrm{PM}_{2.5}$ is the $12^{\text {th }}$ leading risk factor for morbidity and mortality worldwide, mostly due to $\mathrm{CV}$ diseases (23). In terms of PM sources, of particular interest are the so called "supersites" - large cities with dense population, traffic, and pollution such as those in China $(24,25)$. In the US, the National Morbidity, Mortality and Air Pollution Study (NMMAPS) conducted in 90 largest cities found that a $10 \mathrm{mg} / \mathrm{m}^{3}$ increase in $\mathrm{PM}_{10}$ concentration caused a $0.5 \%$ increase in total mortality and $1 \%$ increase in hospital admissions due to CV diseases (26). Similar was reported for Europe (27), and strong associations were found between short-term exposure to $\mathrm{PM}_{10}$ and $\mathrm{PM}_{25}$ and daily all-cause, $\mathrm{CV}$, and respiratory mortality in more than 600 cities across the globe (28). The European Study of Cohorts for Air Pollution Effects (ESCAPE) (29) showed that long-term exposure to additional $5 \mu \mathrm{g} / \mathrm{m}^{3}$ of $\mathrm{PM}_{2.5}$ levels leads to a $13 \%$ increase in non-fatal acute coronary events. Another meta-analysis (30) singled out $\mathrm{PM}_{2.5}$ as more harmful for the CV system than other air pollutants, including $\mathrm{PM}_{10}$. Similarly, two German studies $(31,32)$ established an association between $\mathrm{PM}_{2.5}$ and coronary atherosclerosis in densely populated and highly industrialised areas with dense traffic. High PM $_{2.5}$ concentrations were also associated with blood pressure changes in women due to the traffic pollution in Montreal, Canada (33). In contrast, no significant association was found between $\mathrm{PM}_{25}$ exposure and heavy traffic on New York, Los Angeles, and Chicago roadways (34).

\section{Toxicity mechanisms of particulate matter in cardiovascular diseases}

It is a general agreement that PM affects the CV system through direct and indirect toxicity mechanisms (4). Indirect effects can be triggered by particles of every size, yet only fine and ultrafine PM can affect the heart and blood vessels directly as they enter the alveoli and pass into the systemic circulation $(35,36)$. Another determinant of toxicity mechanisms is exposure duration. Epidemiologic data suggest that short-term PM exposure triggers autonomic response, while long-term exposure triggers inflammatory response (21).

Although the mechanisms of direct PM toxicity to the CV system have not been clearly identified, growing evidence is pointing at reactive oxygen species (ROS) produced by reactions between organic hydrocarbons and transition metals attached to PM $(37,38)$. PM can also directly affect the $\mathrm{CV}$ system by disturbing the calcium ion $\left(\mathrm{Ca}^{2+}\right)$ channel controlling myocardial function, as its imbalance may lead to arrhythmias (39) and can cause vasoconstriction by inhibiting endothelial nitric oxide synthase (eNOS) through the uncoupling action of ROS (7). This mechanism has been supported by findings of impaired nitric oxide-driven vasodilation in humans (40), mice (41) and rats (42) due to exposure to PM from diesel exhaust.

As far as indirect PM mechanisms are concerned, lung oxidative stress and inflammation play a critical role $(3,4)$. PM can trigger inflammation cascade following inhalation $(3,43)$ by upregulating pro-inflammatory cytokines and chemokines, including interleukin (IL-6, IL-8, IL-1 $\beta$, granulocyte macrophage colony-stimulating factor (GM$\mathrm{CSF}$ ), and tumour necrosis factor-alpha (TNF- $\alpha$ ). As these mediators are released into the circulation, the resulting 
systemic inflammatory response can lead to atherosclerosis, which is the cause of many $\mathrm{CV}$ diseases $(4,22,25)$. One study (44) found significant association between $\mathrm{PM}_{2.5}$ from wood combustion and traffic and inflammation markers C-reactive protein, IL-12, and myeloperoxidase, suggesting that $\mathrm{PM}_{25}$ promotes systemic inflammation and risk of development of $\mathrm{CV}$ diseases. In addition, ROS-induced pulmonary inflammation was shown to be linked with atherosclerosis, vascular dysfunction, cardiac arrhythmias, and myocardial infarction (3).

Inflammation can also occur through changes in microRNA (miRNA) expression caused by PM. Several studies have reported that PM can modulate miRNAs involved in inflammation, endothelial dysfunction, and atherosclerosis (45-47).

Another indirect pathway of $\mathrm{PM}_{2.5}$ action involves autonomic imbalance and activation of the sympathetic nervous system $(35,48)$, which affects heart rate variability (HRV) necessary for proper CV function, as cardiac output may vary in response to signals from the autonomic nervous system. In one study (35), ceramic factory workers exposed to PM showed lower HRV and parasympathetic activity and an increased sympathetic activity.

\section{Role of individual differences in particulate matter- related cardiovascular risks}

Not all individuals are equally exposed to or affected by PM in everyday life, even if they share the same environment (49). Individual exposure may vary with lifestyle (such as indoor and outdoor activities), exposure duration, socio-economic circumstances, genetic setup, age, and sex. In fact, according to the 2017 Lancet report by Landrigan et al. (50), about $92 \%$ of pollution-related deaths occur in low- and middle-income countries and minorities, or as the authors succinctly put, "pollution disproportionately kills the poor and the vulnerable". In addition, individuals with pre-existing lung and heart diseases, obesity, diabetes, high levels of LDL cholesterol, high blood pressure, and those physically inactive, smoking tobacco, or having a poor diet are more vulnerable to PM exposure $(4,8,37$, $51)$. For these and other vulnerable groups there is no safe level of exposure or threshold below which no adverse health effects occur (52).

Furthermore, there is a general agreement that long-term (chronic) exposure to PM has more deleterious effects and higher CV mortality than short-term (acute) exposure (3). The latter can destabilise or rupture atherosclerotic plaques and cause cardiac arrhythmias, hypertension, and myocardial infarction $(4,22,53)$. A meta-analysis of reports from China revealed that short-term exposure to both $\mathrm{PM}_{10}$ and $\mathrm{PM}_{2.5}$ was associated with higher mortality, while longterm exposure to $\mathrm{PM}_{10}$ increased the risk of hospital admissions over CV problems (54). Long-term $\mathrm{PM}_{25}$ exposure is also associated with significantly higher mortality due to hypertension (55) and carotid artery thickness (56).

For long, individual exposure to PM had not been measured but relied on environmental indoor or outdoor air monitoring. This has recently changed with the introduction of personal air samplers, which allows us to better evaluate the relations between personal exposure and $\mathrm{CV}$ risk biomarkers $(49,57,58)$ such as blood pressure, systemic inflammation, endothelial function, oxidative stress, antioxidant activity, cardio metabolism, and neuroendocrine stress response established with a variety of methods (59).

\section{Vulnerable populations}

The elderly and children are high-risk populations in terms of exposure to environmental chemicals, even at low doses, since organ systems in children are still under development and the elderly experience the loss of organ function.

A landmark study which involved 22 cities in Europe, 90 in the USA, and 12 in Canada under the Air Pollution and Health: A European Approach (APHEA) project has confirmed an association between acute $\mathrm{PM}_{10}$ exposure and higher CV mortality among subjects over 75 years of age in all three regions, with the greatest effect in Canada (60-62). Similar vulnerability to PM and association with increased all-cause mortality, including $\mathrm{CV}$, and increased rate of $\mathrm{CV}$ diseases in men was observed in the population older than 65 years (63). There is further evidence of association between exposure to $\mathrm{PM}_{10}$ and emergency hospitalisations for $\mathrm{CV}$ diseases in a US population over 65 years of age (63). In Denmark, the association with CV effects was particularly strong in overweight middle-aged and elderly subjects (36). In elderly Chinese men, $\mathrm{PM}_{10}$ was associated with increased risk of CV mortality (64), and in aged Hongkongers $\mathrm{PM}_{2.5}$ was associated with increased risk of CV diseases and ischaemic heart diseases (65).

As a vulnerable group, children are of particular concern, as PM exposure can start in utero and adversely affect health for the rest of their lives $(16,66,67)$. Every day, about $93 \%$ of children under the age of 15 from all over the world (1.8 billion children) are exposed to polluted air, including $\mathrm{PM}_{2.5}$ levels above the WHO guidelines (68). Cumulative lifetime exposure to air pollution in children is dramatically increasing, and recent data indicate that PM exposure, even in utero, leads to increased risk of $\mathrm{CV}$ diseases and associated burden for future generations (69).

These health concerns are heightened by the fact that children are not little adults, as their exposure pathways and toxicokinetics differ from those of the adults (70). Children have higher absorption due to intense anabolic processes, higher number of alveoli, and more permeable respiratory tract. In other words, PM will enter the lungs in children more easily than in adults (71). Moreover, children are more susceptible to the health effects of PM, because their underdeveloped systems and organs are less effective 
at dealing with pollutants (72). Any disruption during these critical years of development can result in severe and lifelong damage, and poor dietary and healthcare conditions can only worsen this damage (73).

Children spend most of their time outdoors, and outdoor air pollution determines the level of PM exposure. There are other factors, including location where they live or go to school, breathing zone, and oxygen consumption, that lead to different responses between children individually and between children and adults. Around two billion children live in areas that exceed the WHO annual limit of $10 \mu \mathrm{g} / \mathrm{m}^{3}$ for $\mathrm{PM}_{2.5}$ (74). Schools may be located in highly polluted places, near highways, power plants, or in industrial sites (71). As for the breathing zone, it is 120 $180 \mathrm{~cm}$ above ground with adults and much closer to the ground with children (75), which implies higher exposure to heavier chemicals (such as mercury) and large particles. Another reason for the greater vulnerability of children is their higher breathing rate and higher oxygen consumption for their body size (71).

Only a few studies have investigated PM-related CV outcomes in children, mostly by measuring blood pressure, as high blood pressure early in life may predict serious CV outcomes later $(58,76,77)$. Recent studies of long- and short-term PM exposure in China have shown an association with hypertension in children and adolescents (78-80). In Belgium, schoolchildren had higher systolic blood pressure on days with higher $\mathrm{PM}_{0.1}$ concentrations (81). In the Netherlands, children aged 12 years had increased systolic and diastolic blood pressure associated with long-term exposure to $\mathrm{PM}_{0.1}$ or $\mathrm{PM}_{2.5}$ in combination with $\mathrm{NO}_{2}(82)$.

Besides blood pressure, one prospective pilot study (83) with 70 children aged $6-18$ investigated their carotid artery intima-media thickness (CIMT; a measure of carotid plaque build-up and atherosclerosis) progression and established its association with traffic-related exposure to $\mathrm{NO}_{\mathrm{x}}$ but not $\mathrm{PM}$ and $\mathrm{O}_{3}$

\section{Air quality in Turkey}

Table 1 shows current daily and annual mean limit values for $\mathrm{PM}_{2.5}$ and $\mathrm{PM}_{10}$ established by various organisations and governments $(6,84-86)$. Turkey has adopted the EU air quality regulations as its goal in its concept of "Air Quality Assessment and Management Regulation" (86).
Urban air pollution is a significant environmental problem for Turkey. Since 1990, it has seen a decrease in $\mathrm{PM}$ and $\mathrm{SO}_{2}$ concentrations in urban areas, as a result of the switch from coal (with high sulphur content) to natural gas in residential heating and power generation (87). Even so, according to the $2010 \mathrm{WHO}$ report, Turkey ranked the second most polluted among 34 countries with $\mathrm{PM}_{10}$ levels above the WHO air quality standard (52). In 2012, the European Environment Agency (EEA) estimated that $97.2 \%$ of the Turkish urban population was exposed to $\mathrm{PM}_{10}$ levels above the daily limit of $50 \mu \mathrm{g} / \mathrm{m}^{3}$ (88).

According to the 2014 WHO Ambient Air Pollution Database, Turkish annual mean levels of $\mathrm{PM}_{25}$ and $\mathrm{PM}_{10}$ were $39 \mu \mathrm{g} / \mathrm{m}^{3}$ and $58 \mu \mathrm{g} / \mathrm{m}^{3}$, respectively, and exceeded the EU and WHO standards $(84,85,89)$.

With increased concern about ambient air PM, so has increased the monitoring and research of $\mathrm{PM}_{25}$ and $\mathrm{PM}_{10}$ levels in Turkey over the last two decades. In 2003, Istanbul as its largest city and Kocaeli as one of the country's most industrialised area in north-western Turkey exceeded the EU annual limits $(90,91)$. Research of PM composition in other air-polluted cities of Turkey, such as Ankara (92), Izmir (93), Sinop (94), Bursa (95), and Kayseri (96) revealed high amounts of toxic trace metals, organic chemicals, and elemental/organic carbon due to a variety of PM sources, including industrial emissions, vehicle exhausts, soil dust, residual oil combustion, and secondary sulphates. In Eskişehir, in central Turkey, daily $\mathrm{PM}_{2.5}$ and $\mathrm{PM}_{10}$ concentrations in 2008/2009 exceeded the EU limit nearly every day and were much higher in the winter due to coal and wood burning for heating (97). High PM $_{10}$ levels in Kütahya in the western part of Turkey were largely owed to open-cast mines and industrial plants (98).

According to the 2018 Chamber of Environmental Engineers air pollution report (99), the most polluted provinces in terms of $\mathrm{PM}_{25}$ were Amasya, Ankara, Artvin, Bartın, Bilecik, Bolu, Bursa, Çanakkale, Çorum, Edirne, Erzurum, İstanbul, Kocaeli, Ordu, Sakarya, Samsun, Sivas, Tekirdağ, Trabzon, Yalova, and Zonguldak. In terms of $\mathrm{PM}_{10}$ the most polluted were Istanbul, Ankara, İzmir, Adana, Kahramanmaraş - Elbistan, Erzurum - Doğubeyazıt, Ağrı - Taşhan, Iğdır, Bursa, Mersin, Bursa, Niğde, Erzincan, Denizli, Afyon, and Muğla.

Despite the increasing number of air quality studies in Turkey, only a few Turkish studies (100-103) have

Table 1 Current air quality limit values for $\mathrm{PM}_{2.5}$ and $\mathrm{PM}_{10}$

\begin{tabular}{|l|c|c|c|c|}
\hline \multirow{2}{*}{ Country / Organisation (reference) } & \multicolumn{4}{|c|}{ Limit values (mean) } \\
\cline { 2 - 5 } & \multicolumn{2}{|c|}{ PM $_{2.5}$} & \multicolumn{2}{c|}{ PM $_{10}$} \\
\cline { 2 - 5 } & Daily & Annual & Daily & Annual \\
\hline WHO (84) & $25 \mu \mathrm{g} / \mathrm{m}^{3}$ & $10 \mu \mathrm{g} / \mathrm{m}^{3}$ & $50 \mu \mathrm{g} / \mathrm{m}^{3}$ & $20 \mu \mathrm{g} / \mathrm{m}^{3}$ \\
\hline US EPA (6) & $35 \mu \mathrm{g} / \mathrm{m}^{3}$ & $12 \mu \mathrm{g} / \mathrm{m}^{3}$ & $150 \mu \mathrm{g} / \mathrm{m}^{3}$ & - \\
\hline EU (85) & - & $25 \mu \mathrm{g} / \mathrm{m}^{3}$ & $50 \mu \mathrm{g} / \mathrm{m}^{3}$ & $40 \mu \mathrm{g} / \mathrm{m}^{3}$ \\
\hline Turkey (86) & - & - & $50 \mu \mathrm{g} / \mathrm{m}^{3}$ & $40 \mu \mathrm{g} / \mathrm{m}^{3}$ \\
\hline
\end{tabular}

WHO - World Health Organization; US EPA - United States Environmental Protection Agency; EU - European Union 
evaluated PM-related health effects and risks in the nation, none of which specifically include $\mathrm{CV}$ diseases or mortality. An exception, to some extent, is a small study in 46 Turkish women, which established an association between biomass fuel exposure and high ventricular systolic blood pressure and low myocardial indices, indicating decreased biventricular systolic function (104). Biomass fuels include wood, charcoal, and crop residue, which are burned for cooking and heating and are known to emit $\mathrm{PM}_{2.5}$ and increase the risk of CV diseases (105).

However, there is a large multinational prospective cohort study PURE (106), which included participants from Turkey and found that long-term outdoor $\mathrm{PM}_{2.5}$ levels were related to increased risk of $\mathrm{CV}$ diseases in adults aged $35-70$. A $10 \mu \mathrm{g}$ increase was associated with a $3 \%$ increase in the risk of CV deaths, a $5 \%$ increase in $\mathrm{CV}$ events, a $3 \%$ increase in myocardial infarction, and an $8 \%$ increase in stroke (107). In addition, the study found a strong association between long-term $\mathrm{PM}_{2.5}$ exposure and hypertension (108).

\section{Prevention of particulate matter-related cardiovascular outcomes}

Air pollution is controllable, and many of its adverse health effects can be prevented (16). The WHO estimates that reducing $\mathrm{PM}_{10}$ pollution from 70 to $20 \mu \mathrm{g} / \mathrm{m}^{3}$ can lower the related death rate by $15 \%$ (1). Laden et al. (109) have shown that a $10 \mu \mathrm{g} / \mathrm{m}^{3}$ reduction in $\mathrm{PM}_{2.5}$ led to a $31 \%$ reduction in CV mortality rates, and Clancy et al. (110) stated that the ban on coal burning in Ireland lowered CV mortality by $10.3 \%$ and CV morbidity by $7 \%$. In Australia, $\mathrm{PM}_{10}$ reduction by $25 \%$ annually and by $38 \%$ in the winter was reported to have lowered CV morbidity by $17.9 \%$ and $19.6 \%$, respectively (111).

National and international regulatory authorities put forward risk assessment strategies, propose and revise PM limits, and intervene on the public level. However, there are also ways of individual prevention with high-efficiency particulate air (HEPA) filter face masks for short periods of acute PM exposure (48) or with exhaust particulate traps fitted on vehicles (112).

In Europe, PM concentrations are expected to drop substantially by 2030 with stricter regulations of car exhaust and residential emissions (43). For instance, in the Czech Republic, residential heating with coal accounted for $70 \%$ of the $\mathrm{PM}_{10}$ pollution, so the government supported its replacement with natural gas, which resulted in low $\mathrm{SO}_{2}$ and $\mathrm{PM}_{10}$ pollution levels and a decline in $\mathrm{CV}$ mortality (113). The above mentioned ban on coal burning in Dublin, Ireland and new regulation in Launceston, Australia, both effectively lowered $\mathrm{PM}_{10}$ levels and $\mathrm{CV}$ and respiratory mortality and morbidity $(110,111)$.

\section{CONCLUSION}

Numerous experimental and epidemiological studies have clearly established the risks of CV morbidity and mortality associated with PM, and future studies of its toxicity mechanisms are required to better understand its direct and indirect effects on the cardiovascular system. Understanding the mechanisms of PM toxicity, especially in vulnerable groups such as children, will help to devise effective air pollution regulations and improve the existing ones to minimise health risks. Interventions on national and personal level have already shown their potential to reduce PM exposure and prevent adverse health effects, but this is a continuous battle, and Turkey has a long way to go in this respect.

\section{Conflict of interests}

None to declare.

\section{Acknowledgments}

This manuscript was edited for English language by Gazi University Academic Writing Application and Research Center.

\section{REFERENCES}

1. World Health Organization. Ambient (outdoor) air pollution. 2021 [displayed 5 November 2021]. Available at https://www. who.int/news-room/fact-sheets/detail/ambient-(outdoor)-airquality-and-health

2. International Agency for Research on Cancer. Outdoor air pollution. IARC monographs on the evaluation of carcinogenic risks to humans. Volume 109. Lyon: IARC; 2016 [displayed 10 November 2021]. Available at https://publications.iarc.fr/ Book-And-Report-Series/Iarc-Monographs-On-TheIdentification-Of-Carcinogenic-Hazards-To-Humans/OutdoorAir-Pollution-2015

3. Du Y, Xu X, Chu M, Guo Y, Wang J. Air particulate matter and cardiovascular disease: the epidemiological, biomedical and clinical evidence. J Thorac Dis 2016;8:E8-19. doi: 10.3978/j.issn.2072-1439.2015.11.37

4. Nelin TD, Joseph AM, Gorr MW, World LE. Direct and indirect effects of particulate matter on the cardiovascular system. Toxicol Lett 2012;208:293-9. doi: 10.1016/j. toxlet.2011.11.008.

5. Xing YF, Xu YH, Shi MH, Lian YX. The impact of $\mathrm{PM}_{2.5}$ on the human respiratory system. J Thorac Dis 2016;8:E69-74. doi: 10.3978/j.issn.2072-1439.2016.01.19

6. United States Environmental Protection Agency. Particulate Matter (PM) Pollution. Particulate Matter (PM) Basics [displayed 13 January 2021]. Available at https://www.epa. gov/pm-pollution/particulate-matter-pm-basics

7. Lawal AO, Davids LM, Marnewick JL. Diesel exhaust particles and endothelial cells dysfunction: An update. Toxicol in Vitro 2016;32:92-104. doi: 10.1016/j.tiv.2015.12.015

8. Bae S, Hong YC. Health effects of particulate matter. J Korean MedAssoc 2018;61:749-55. doi: 10.5124/jkma.2018.61.12.749 
9. Fang D, Huang W, Antkiewicz DS, Wang Y, Khuzestani RB, Zhang Y, Shang J, Shafer MM, He L, Schauer JJ, Zhang Y, Zhao S. Chemical composition and health risk indices associated with size-resolved particulate matter in Pearl River Delta (PRD) region, China. Environ Sci Pollut Res 2019;26:12435-45. doi: 10.1007/s11356-019-04618-z

10. Corsini E, Marinovich M, Vecchi R. Ultrafine particles from residential biomass combustion: A review on experimental data and toxicological response. Int J Mol Sci 2019;20:4992. doi: 10.3390/ijms20204992

11. Donaldson K, Duffin R, Langrish JP, Miller MR, Mills NL, Poland CA, Raftis J, Shahv A, Shaw CA, Newby DE. Nanoparticles and the cardiovascular system: A critical review. Nanomedicine 2013;8:403-23. doi: 10.2217/nnm.13.16

12. Landkocz Y, Ledoux F, André V, Cazier F, Genevray P, Dewaele D, Martin PJ, Lepers C, Verdin A, Courcot L, Boushina S, Sichel F, Gualtieri M, Shirali P, Courcot D, Billet $\mathrm{S}$. Fine and ultrafine atmospheric particulate matter at a multiinfluenced urban site: Physicochemical characterization, mutagenicity and cytotoxicity. Environ Pollut 2017;221:130 40. doi: 10.1016/j.envpol.2016.11.054

13. de Kok TMCM, Driece HAL, Hogervorst JGF, Briedé JJ. Toxicological assessment of ambient and traffic-related particulate matter: A review of recent studies. Mut Res 2006;613:103-22. doi: 10.1016/j.mrrev.2006.07.001

14. Morakinyo OM, Mokgobu MI, Mukhola MS, Hunter RP. Health outcomes of exposure to biological and chemical components of inhalable and respirable particulate matter. Int J Environ Res Public Health 2016;13:592. doi: 10.3390/ ijerph13060592

15. Sioutas C, Delfino RJ, Singh M. Exposure assessment for atmospheric Ultrafine Particles (UFPs) and implications in epidemiologic research. Environ Health Persp 2005;947-55. doi: 10.1289/ehp.7939

16. Schraufnagel DE, Balmes JR, Cowl CT, De Matteis S, Jung SH, Mortimer K, Perez-Padilla R, Rice MB, Riojas-Rodriguez H, Sood A, Thurston GD, To T, Vanker A, Wuebbles DJ. Air pollution and noncommunicable diseases: A review by the forum of International Respiratory Societies' Environmental Committee, Part 2: Air pollution and organ systems. Chest 2019;155:417-26. doi: 10.1016/j.chest.2018.10.041

17. Lelieveld J, Klingmüller K, Pozzer A, Pöschl U, Fnais M, Daiber A, Münzel T. Cardiovascular disease burden from ambient air pollution in Europe reassessed using novel hazard ratio functions. Eur Heart J 2019;40:1590-6. doi: 10.1093/ EURHEARTJ/EHZ135

18. Hvidtfeldt UA, Sørensen M, Geels C, Ketzel M, Khan J, Tjønneland A, Overvad K, Brandt J, Raaschou-Nielsen O. Long-term residential exposure to $\mathrm{PM}_{25}, \mathrm{PM}_{10}$, black carbon, $\mathrm{NO}_{2}$, and ozone and mortality in a Danish cohort. Environ Int 2019;123:265-72. doi: 10.1016/j.envint.2018.12.010

19. Zhang C, Ding R, Xiao C, Xu Y, Cheng H, Zhu F, Lei R, Di D, Zhao Q, Cao J. Association between air pollution and cardiovascular mortality in Hefei, China: A time-series analysis. Environ Pollut 2017;229:790-7. doi: 10.1016/j. envpol.2017.06.022

20. Khaniabadi YO, Goudarzi G, Daryanoosh SM, Borgini A, Tittarelli A, De Marco A. Exposure to $\mathrm{PM}_{10}, \mathrm{NO}_{2}$, and $\mathrm{O}_{3}$ and impacts on human health. Environ Sci Pollut Res 2017;24:27819. doi: 10.1007/s11356-016-8038-6

21. Farraj AK, Walsh L, Haykal-Coates N, Malik F, McGee J, Winsett D, Duvall R, Kovalcik K, Cascio WE, Higuchi M,
Hazari MS. Cardiac effects of seasonal ambient particulate matter and ozone co-exposure in rats. Part Fibre Toxicol 2015;12:12. doi: 10.1186/s12989-015-0087-3

22. Brook RD, Rajagopalan S, Pope CA, Brook JR, Bhatnagar A, Diez-Roux AV, Holguin F, Hong Y, Luepker RV, Mittleman MA, Peters A, Siscovick D, Smith Jr SC, Whitsel L, Kaufman JD; American Heart Association Council on Epidemiology and Prevention, Council on the Kidney in Cardiovascular Disease, and Council on Nutrition, Physical Activity and Metabolism. Particulate matter air pollution and cardiovascular disease: An update to the scientific statement from the American Heart Association. Circulation 2010;121:2331-78. doi: 10.1161/CIR.0b013e3181dbece1

23. Maciejewska K. Short-term impact of $\mathrm{PM}_{25}, \mathrm{PM}_{10}$, and PMc on mortality and morbidity in the agglomeration of Warsaw, Poland. Air Qual Atmos Health 2020;13:659-72. doi: 10.1007/ s11869-020-00831-9

24. Lelieveld J, Pöschl U. Chemists can help to solve the airpollution health crisis. Nature 2017;551:291-3. doi: 10.1038/ d41586-017-05906-9

25. Kajbafzadeh M, Brauer M, Karlen B, Carlsten C, Van Eeden $\mathrm{S}$, Allen RW. The impacts of traffic-related and woodsmoke particulate matter on measures of cardiovascular health: A HEPA filter intervention study. Occup Environ Med 2015;72:394-400. doi: 10.1136/oemed-2014-102696

26. United States Environmental Protection Agency. The National Morbidity, Mortality, and Air Pollution Study: Morbidity and Mortality from Air Pollution in the United States [displayed 10 November 2021]. Available at https://cfpub.epa.gov/ ncer_abstracts/index.cfm/fuseaction/display.abstractDetail/ abstract id $/ 2399 /$ report $/ 0$

27. Wolf K, Stafoggia M, Cesaroni G, Andersen ZJ, Beelen R, Galassi C, Hennig F, Migliore E, Penell J, Ricceri F, Sørensen M, Turunen AW, Hampel R, Hoffmann B, Kälsch H, Laatikainen T, Pershagen G, Raaschou-Nielsen O, Sacerdote C, Vineis P, Badaloni C, Cyrys J, de Hoogh K, Eriksen KT, Jedynska A, Keuken M, Kooter I, Lanki T, Ranzi A, Sugiri D, Tsai M-Y, Wang M, Hoek G, Brunekreef B, Peters A, Forastiere F. Long-term exposure to particulate matter constituents and the incidence of coronary events in 11 European cohorts. Epidemiology 2015;26:565-74. doi: 10.1097/ EDE.0000000000000300

28. Liu C, Chen R, Sera F, Vicedo-Cabrera AM, Guo Y, Tong S, Coelho MSZS, Saldiva PHN, Lavigne E, Matus P, Valdes Ortega N, Osorio Garcia S, Pascal M, Stafoggia M, Scortichini M, Hashizume M, Honda Y, Hurtado-Díaz M, Cruz J, Nunes B, Teixeira JP, Kim H, Tobias A, Íñiguez C, Forsberg B, Åström C, Ragettli MS, Guo Y-L, Chen B-Y, Bell ML, Wright CY, Scovronick N, Garland RM, Milojevic A, Kyselý J, Urban A, Orru H, Indermitte E, Jaakkola JJK, Ryti NRI, Katsouyanni K, Analitis A, Zanobetti A, Schwartz J, Chen J, Wu T, Cohen A, Gasparrini A, Kan H. Ambient particulate air pollution and daily mortality in 652 cities. New Engl J Med 2019;381:70515. doi: 10.1056/NEJMoa1817364

29. Beelen R, Raaschou-Nielsen O, Stafoggia M, Andersen ZJ, Weinmayr G, Hoffmann B, Wolf K, Samoli E, Fischer P, Nieuwenhuijsen M, Vineis P, Xun WW, Katsouyanni K, Dimakopoulou K, Oudin A, Forsberg B, Modig L, Havulinna AS, Lanki T, Turunen A, Oftedal B, Nystad W, Nafstad P, De Faire U, Pedersen NL, Östenson C-G, Fratiglioni L, Penell J, Korek M, Pershagen G, Eriksen KT, Overvad K, Ellermann T, Eeftens M, Peeters PH, Meliefste K, Wang M, Bueno-de- 
Mesquita B, Sugiri D, Krämer U, Heinrich J, de Hoogh K, Key T, Peters A, Hampel R, Concin H, Nagel G, Ineichen A, Schaffner E, Probst-Hensch N, Künzli N, Schindler C, Schikowski T, Adam M, Phuleria H, Vilier A, Clavel-Chapelon F, Declercq C, Grioni S, Krogh V, Tsai M-Y, Ricceri F, Sacerdote C, Galassi C, Migliore E, Ranzi A, Cesaroni G, Badaloni C, Forastiere F, Tamayo I, Amiano P, Dorronsoro M, Katsoulis M, Trichopoulou A, Brunekreef B, Hoek G. Effects of long-term exposure to air pollution on natural-cause mortality: An analysis of 22 European cohorts within the multicentre ESCAPE project. The Lancet 2014;383:785-95. doi: 10.1016/S0140-6736 (13)62158-3

30. Luo C, Zhu X, Yao C, Hou L, Zhang J, Cao J, Wang A. Shortterm exposure to particulate air pollution and risk of myocardial infarction: a systematic review and meta-analysis. Environ Sci Pollut Res Int 2015;22:14651-62. doi: 10.1007/s11356-0155188-x

31. Hoffmann B, Moebus S, Möhlenkamp S, Stang A, Lehmann N, Dragano N, Schmermund A, Memmesheimer M, Mann K, Erbel R, Jöckel K-H; Heinz Nixdorf Recall Study Investigative Group. Residential exposure to traffic is associated with coronary atherosclerosis. Circulation 2007;116:489-96. doi: 10.1161/CIRCULATIONAHA.107.693622

32. Hoffmann B, Moebus S, Dragano N, Möhlenkamp S, Memmesheimer M, Erbel R, Jöckel K-H; Heinz Nixdorf Recall Investigative Group. Residential traffic exposure and coronary heart disease: Results from the Heinz Nixdorf Recall Study. Biomarkers 2009;14(Suppl 1):74-8. doi: 10.1080/13547500902965096

33. Weichenthal S, Hatzopoulou M, Goldberg MS. Exposure to traffic-related air pollution during physical activity and acute changes in blood pressure, autonomic and micro-vascular function in women: A cross-over study. Part Fibre Toxicol 2014;11:70. doi: 10.1186/s12989-014-0070-4

34. Allen RW, Criqui MH, Diez Roux AW, Allison M, Shea S, Detrano R, Sheppard L, Wong ND, Stukovsky KH, Kaufman JD. Fine particulate matter air pollution, proximity to traffic, and aortic atherosclerosis. Epidemiology 2009;20:254-64. doi: 10.1097/EDE.0b013e31819644cc

35. Bortkiewicz A, Gadzicka E, Stroszejn-Mrowca G, Szyjkowska A, Szymczak W, Koszada-Włodarczyk W, SzadkowskaStańczyk I. Cardiovascular changes in workers exposed to fine particulate dust. Int J Occup Med Environ Health 2014;27:78 92. doi: $10.2478 / \mathrm{s} 13382-014-0234-3$

36. Nasser Z, Salameh P, Nasser W, Abou Abbas L, Elias E, Leveque A. Outdoor particulate matter (PM) and associated cardiovascular diseases in the Middle East. Int J Occup Med Environ Health 2015;28:641-61. doi: 10.13075/ ijomeh.1896.00186

37. Hemmingsen JG, Rissler J, Lykkesfeldt J, Sallsten G, Kristiansen J, P PM, Loft S. Controlled exposure to particulate matter from urban street air is associated with decreased vasodilation and heart rate variability in overweight and older adults. Part Fibre Toxicol 2015;12:1-10. doi: 10.1186/s12989015-0081-9

38. Bai Y, Suzuki AK, Sagai M. The cytotoxic effects of diesel exhaust particles on human pulmonary artery endothelial cells in vitro: Role of active oxygen species. Free Rad Biol Med 2001;30:555-62. doi: 10.1016/S0891-5849 (00)00499-8

39. Mandal A, Chakraborti T, Chakraborti S. Calcium handling in pulmonary vasculature under oxidative stress: Focus on SERCA. In: Chakraborti S, Dhalla NS, editors. Regulation of
Ca2+-ATPases, V-ATPases and F-ATPases. Cham: Springer International Publishing; 2016. p. 207-26.

40. Langrish JP, Unosson J, Bosson J, Barath S, Muala A, Blackwell S, Söderberg S, Pourazar J, Megson IL, Treweeke A, Sandström T, Newby DE, Blomberg A, Mills NL. Altered nitric oxide bioavailability contributes to diesel exhaust inhalation-induced cardiovascular dysfunction in man. J Am Heart Assoc 2013;2:e004309. doi: 10.1161/JAHA.112.004309

41. Knuckles TL, Lund AK, Lucas SN, Campen MJ. Diesel exhaust exposure enhances venoconstriction via uncoupling of eNOS. Toxicol Appl Pharmacol 2008;230:346-51. doi: 10.1016/j.taap.2008.03.010

42. Miller MR, Borthwick SJ, Shaw CA, McLean SG, McClure D, Mills NL, Duffin R, Donaldson K, Megson IL, Hadoke PWF, Newby DE. Direct impairment of vascular function by diesel exhaust particulate through reduced bioavailability of endothelium-derived nitric oxide induced by superoxide free radicals. Environ Health Perspect 2009;117:611-6. doi: 10.1289/ehp.0800235

43. Daellenbach KR, Uzu G, Jiang J, Cassagnes LE, Leni Z, Vlachou A, Stefenelli G, Canonaco F, Weber S, Segers A, Kuenen JJP, Schaap M, Favez O, Albinet A, Aksoyoglu S, Dommen J, Baltensperger U, Geiser M, El Haddad I, Jaffrezo J-L, Prévôt ASH. Sources of particulate-matter air pollution and its oxidative potential in Europe. Nature 2020;587:414-9. doi: 10.1038/s41586-020-2902-8

44. Siponen T, Yli-Tuomi T, Aurela M, Dufva H, Hillamo R, Hirvonen MR, Huttunen K, Pekkanen J, Pennanen A, Salonen I, Tiittanen P, Salonen RO, Lanki T. Source-specific fine particulate air pollution and systemic inflammation in ischaemic heart disease patients. Occup Environ Med 2015;72:277-83. doi: 10.1136/oemed-2014-102240

45. Bollati V, Iodice S, Favero C, Angelici L, Albetti B, Cacace R, Cantone L, Carugno M, Cavalleri T, De Giorgio B, Dioni L, Fustinoni S, Hoxha M, Marinelli B, Motta V, Patrini L, Pergoli L, Riboldi L, Rizzo G, Rota F, Sucato S, Tarantini L, Tirelli AS, Vigna L, Bertazzi P, Pesatori AC. Susceptibility to particle health effects, miRNA and exosomes: Rationale and study protocol of the SPHERE study. BMC Public Health 2014;14:1137. doi: 10.1186/1471-2458-14-1137

46. Fossati S, Baccarelli A, Zanobetti A, Hoxha M, Vokonas PS, Wright RO, Schwartz J. Ambient particulate air pollution and MicroRNAs in elderly men. Epidemiology 2014;25:68-78. doi: 10.1097/EDE.0000000000000026

47. Wilker EH, Alexeeff SE, Suh H, Vokonas PS, Baccarelli A, Schwartz J. Ambient pollutants, polymorphisms associated with microRNA processing and adhesion molecules: The Normative Aging Study. Environ Health 2011;10:45. doi: 10.1186/1476-069X-10-45

48. Morishita M, Thompson KC, Brook RD. Understanding air pollution and cardiovascular diseases: Is it preventable? Curr Cardiovasc Risk Rep 2015;9:30. doi: 10.1007/s12170-0150458-1

49. Brook RD, Bard RL, Burnett RT, Shin HH, Vette A, Croghan C, Phillips M, Rodes C, Thornburg J, Williams R. Differences in blood pressure and vascular responses associated with ambient fine particulate matter exposures measured at the personal versus community level. Occup Environ Med 2011;68:224-30. doi: 10.1136/oem.2009.053991

50. Landrigan PJ, Fuller R, Acosta NJR, Adeyi O, Arnold R, Basu NN, Baldé AB, Bertollini R, Bose-O'Reilly S, Boufford JI, Breysse PN, Chiles T, Mahidol C, Coll-Seck AM, Cropper 
ML, Fobil J, Fuster V, Greenstone M, Haines A, Hanrahan D, Hunter D, Khare M, Krupnick A, Lanphear B, Lohani B, Martin K, Mathiasen KV, McTeer MA, Murray CJL, Ndahimananjara JD, Perera F, Potočnik J, Preker AS, Ramesh J, Rockström J, Salinas C, Samson LD, Sandilya K, Sly PD, Smith KR, Steiner A, Stewart RB. The Lancet Commission on pollution and health. Lancet 2018;381:462-512. doi: 10.1016/S0140-6736 (17)32345-0

51. Pope CA, Muhlestein JB, Anderson JL, Cannon JB, Hales NM, Meredith KG, Le V, Horne BD. Short-term exposure to fine particulate matter air pollution is preferentially associated with the risk of ST-segment elevation acute coronary events. J Am Heart Assoc 2015;4:e002506. doi: 10.1161/ JAHA.115.002506

52. World Health Organization. Health effects of particulate matter Policy implications for countries in eastern Europe, Caucasus and central Asia. WHO: Copenhagen; 2013 [displayed 10 November 2021]. Available at https://www.euro.who.int/en/ health-topics/environment-and-health/air-quality/ publications/2013/health-effects-of-particulate-matter--policyimplications-for-countries-in-eastern-europe,-caucasus-andcentral-asia-2013

53. Brook RD, Rajagopalan S. Particulate matter air pollution and atherosclerosis. Curr Atheroscler Rep 2010;12:291-300. doi: 10.1007/s11883-010-0122-7

54. Lu F, Xu D, Cheng Y, Dong S, Guo C, Jiang X, Zheng X. Systematic review and meta-analysis of the adverse health effects of ambient $\mathrm{PM}_{25}$ and $\mathrm{PM}_{10}$ pollution in the Chinese population. Environ Res 2015;136:196-204. doi: 10.1016/j. envres.2014.06.029

55. Pope CA, Turner MC, Burnett RT, Jerrett M, Gapstur SM, Diver WR, Krewski D, Brook RD. Relationships between fine particulate air pollution, cardiometabolic disorders, and cardiovascular mortality. Circ Res 2015;116:108-15. doi: 10.1161/CIRCRESAHA.116.305060

56. Künzli N, Jerrett M, Mack WJ, Beckerman B, LaBree L, Gilliland F, Thomas D, Peters J, Hodis HN. Ambient air pollution and atherosclerosis in Los Angeles. Environ Health Persp 2005;113:201-6. doi: 10.1289/ehp.7523

57. Xia B, Zhou Y, Zhu Q, Zhao Y, Wang Y, Ge W, Yang Q, Zhao Y, Wang P, Si J, Luo R, Li J, Shi H, Zhang Y. Personal exposure to $\mathrm{PM}_{25}$ constituents associated with gestational blood pressure and endothelial dysfunction. Environ Pollut 2019;250:346-56. doi: 10.1016/j.envpol.2019.04.024

58. Yang H, Teng C, Hu J, Zhu X, Wang Y, Wu J-Z, Xiao Q, Yang W, Shen H, Liu F. Short-term effects of ambient particulate matter on blood pressure among children and adolescents: A cross-sectional study in a city of Yangtze River delta, China. Chemosphere 2019;237:124510. doi: 10.1016/j. chemosphere.2019.124510

59. Lin Z, Chen R, Jiang Y, Xia Y, Niu Y, Wang C, Liu C, Chen C, Ge Y, Wang W, Yin G, Cai J, Clement V, Xu X, Chen B, Chen H, Kan H. Cardiovascular benefits of fish-oil supplementation against fine particulate air pollution in China. J Am Coll Cardiol 2019;73:2076-85. doi: 10.1016/j. jacc.2018.12.093

60. Samoli E, Touloumi G, Zanobetti A, Le Tertre A, Schindler C, Atkinson R, Vonk J, Rossi G, Saez M, Rabczenko D, Schwartz $\mathrm{J}$, Katsouyanni K. Investigating the dose-response relation between air pollution and total mortality in the APHEA-2 multicity project. Occup Environ Med 2003;60:977-82. doi: 10.1136/oem.60.12.977
61. Samoli E, Analitis A, Touloumi G, Schwartz J, Anderson HR, Sunyer J, Bisanti L, Zmirou D, Vonk JM, Pekkanen J, Goodman P, Paldy A, Schindler C, Katsouyanni K. Estimating the exposure-response relationships between particulate matter and mortality within the APHEA multicity project. Environ Health Perspect 2005;113:88-95. doi: 10.1289/ehp.7387

62. Samoli E, Peng R, Ramsay T, Pipikou M, Touloumi G, Dominici F, Burnett R, Cohen A, Krewski D, Samet J, Katsouyanni K. Acute effects of ambient particulate matter on mortality in Europe and North America: Results from the APHENA study. Environ Health Perspect 2008;116:1480-6. doi: $10.1289 /$ ehp. 11345

63. Powell H, Krall JR, Wang Y, Bell ML, Peng RD. Ambient coarse particulate matter and hospital admissions in the Medicare Cohort Air Pollution Study, 1999-2010. Environ Health Perspect 2015;123:1152-8. doi: 10.1289/ehp.1408720

64. Zhou M, Liu Y, Wang L, Kuang X, Xu X, Kan H. Particulate air pollution and mortality in a cohort of Chinese men. Environ Pollut 2014;186:1-6. doi: 10.1016/j.envpol.2013.11.010

65. Wong CM, Lai HK, Tsang H, Thach TQ, Neil Thomas G, Lam KBH, Chan, Lin Yang KP, Lau AKH, Ayres JG, Lee SY, Chan WM, Hedley AJ, Lam TH. Satellite-based estimates of longterm exposure to fine particles and association with mortality in elderly Hong Kong residents. Environ Health Perspect 2015;123:1167-72. doi: 10.1289/ehp.1408264

66. Lin WW, Chen ZX, Kong ML, Xie YQ, Zeng XW. Air pollution and children's health in Chinese. Adv Exp Med Biol 2017;1017:153-80. doi: 10.1007/978-981-10-5657-4 7

67. Landrigan PJ, Fuller R, Hu H, Caravanos J, Cropper ML, Hanrahan D, Sandilya K, Chiles TC, Kumar P, Suk WA. Pollution and global health - An agenda for prevention. Environ Health Perspect 2018;126(8):084501. doi: 10.1289/ EHP3141

68. World Health Organization. Air pollution and child health: prescribing clean air [displayed 19 September 2021]. Available at https://www.who.int/publications/i/item/air-pollution-andchild-health

69. Kim JB, Prunicki M, Haddad F, Dant C, Sampath V, Patel R, Smith E, Akdis C, Balmes J, Snyder MP, Wu JC, Nadeau KC. Cumulative lifetime burden of cardiovascular disease from early exposure to air pollution. J Am Heart Assoc 2020;9:e014944. doi: 10.1161/JAHA.119.014944

70. Carroquino MJ, Posada M, Landrigan PJ. Environmental toxicology: children at risk. In: Laws EA, editor. Environmental Toxicology: Selected Entries from the Encyclopedia of Sustainability Science and Technology. New York: Springer; 2013. p.293-91. doi: 10.1007/978-1-4614-5764-0 11

71. Bearer CF. Environmental health hazards: how children are different from adults. Future Child 1995;5:11-26. doi: $10.2307 / 160235$

72. Ferguson A, Penney R, Solo-Gabriele H. A review of the field on children's exposure to environmental contaminants: A risk assessment approach. Int J Environ Res Public Health 2017;14:265. doi: 10.3390/ijerph14030265

73. Pure Earth Blacksmith Institute. 2015 World's Worst Pollution Problems. The New Top Six Toxic Threats: A Priority List for Remediation [displayed 19 September 2021]. Available at https://www.worstpolluted.org/docs/WWP15.pdf

74. United Nations International Children's Emergency Fund (UNICEF). Clear the air for children / The impact of air pollution on children [displayed 26 October 2021]. Available 
at https://www.unicef.org/media/49966/file/UNICEF_Clear_ the_Air_for_Children_30_Oct_2016.pdf

75. Etzel RA. The special vulnerability of children. Int J Hyg Environ Health 2020;227:113516. doi: 10.1016/j. ijheh.2020.113516

76. Madhloum N, Nawrot TS, Gyselaers W, Roels HA, Bijnens E, Vanpoucke C, Lefebvre W, Janssen BG, Cox B. Neonatal blood pressure in association with prenatal air pollution exposure, traffic, and land use indicators: An ENVIRONAGE birth cohort study. Environ Int 2019;130:104853. doi: 10.1016/j.envint.2019.05.047

77. Sughis M, Nawrot TS, Ihsan-ul-Haque S, Amjad A, Nemery B. Blood pressure and particulate air pollution in schoolchildren of Lahore, Pakistan. BMC Public Health 2012;12:378. doi: 10.1186/1471-2458-12-378

78. Zhang Z, Dong B, Li S, Chen G, Yang Z, Dong Y, Wang Z, Ma J, Guo Y. Exposure to ambient particulate matter air pollution, blood pressure and hypertension in children and adolescents: A national cross-sectional study in China. Environ Int 2019;128:103-8. doi: 10.1016/j.envint.2019.04.036

79. Wang X, Zou Z, Dong B, Dong Y, Ma Y, Gao D, Yang Z, Wu $\mathrm{S}$, Ma J. Association of school residential $\mathrm{PM}_{2.5}$ with childhood high blood pressure: results from an observational study in 6 cities in China. Int J Environ Res Public Health 2019;16:2515. doi: 10.3390/ijerph16142515

80. Zeng XW, Qian Z (Min), Vaughn MG, Nelson EJ, Dharmage SC, Bowatte G, Perret J, Chen D-H, Ma H, Lin S, de Foy B, Hu L-W, Yang B-Y, Xu S-L, Zhang C, Tian Y-P, Nian M, Wang J, Xiao X, Bao W-W, Zhang Y-Z, Dong G-H. Positive association between short-term ambient air pollution exposure and children blood pressure in China - Result from the Seven Northeast Cities (SNEC) study. Environ Pollut 2017;224:698 705. doi: 10.1016/j.envpol.2017.02.054

81. Pieters N, Koppen G, Poppel M Van, Prins S De, Cox B, Dons E, Nelen V, Panis LI, Plusquin M, Schoeters G, Nawrot TS. Blood pressure and same-day exposure to air pollution at school: Associations with nano-sized to coarse PM in children. Environ Health Perspect 2015;123:737-42. doi: 10.1289/ EHP.1408121

82. Bilenko N, van Rossem L, Brunekreef B, Beelen R, Eeftens M, Hoek G, Houthuijs D, de Jongste JC, van Kempen E, Koppelman GH, Meliefste K, Oldenwening M, Smit HA, Wijga AH, Gehring U. Traffic-related air pollution and noise and children's blood pressure: Results from the PIAMA birth cohort study. Eur J Prev Cardiol 2015;22:4-12. doi: $10.1177 / 2047487313505821$

83. Farzan SF, Habre R, Danza P, Lurmann F, Gauderman WJ, Avol E, Bastain T, Hodis H-N, Breton C. Childhood trafficrelated air pollution and adverse changes in subclinical atherosclerosis measures from childhood to adulthood. Environ Health 2021;20:44. doi: 10.1186/S12940-021-00726-x

84. World Health Organization. WHO Air quality guidelines for particulate matter, ozone, nitrogen dioxide and sulfur dioxide, Global update 2005 [displayed 22 April 2021]. Available at https://apps.who.int/iris/handle/10665/69477

85. European Commission. Air Quality Standards [displayed 26 October 2021]. Available at https://ec.europa.eu/environment/ air/quality/standards.htm

86. Hava kalitesi değerlendirme ve yönetimi yönetmeliği [Air quality assessment and management regulation, in Turkish] Resmi Gazete 2008/26898. [displayed 5 November 2021]. Available at https://www.mevzuat.gov.tr/ $\mathrm{mevzu}$ a t ? M e v z u a t $\mathrm{No}=12188$ $\&$ MevzuatTur $=7 \&$ MevzuatTertip $=5$

87. Büke T, Köne AÇ. Assessing air quality in Turkey: A proposed, air quality index. Sustainability 2016;8:73. doi: 10.3390/ su8010073

88. European Environment Agency. Air pollution fact sheet 2014 / Turkey [displayed 26 October 2021]. Available at https:// www.eea.europa.eu/themes/air/air-pollution-country-factsheets-2014/turkey-air-pollutant-emissions-country-factsheet/ view

89. Health and Environment Alliance (HEAL). Air pollution and health in Turkey. [displayed 26 October 2021]. Available at: https://www.eea.europa.eu/themes/air/air-pollution-countryfact-sheets-2014/turkey-air-pollutant-emissions-countryfactsheet/at download/file

90. Karaca F, Alagha O, Ertürk F. Statistical characterization of atmospheric $\mathrm{PM}_{10}$ and $\mathrm{PM}_{2.5}$ concentrations at a non-impacted suburban site of Istanbul, Turkey. Chemosphere 2005;59:1183 90. doi: 10.1016/j.chemosphere.2004.11.062

91. Pekey B, Bozkurt ZB, Pekey H, Doĝan G, Zararsiz A, Efe N, Tuncel G. Indoor/outdoor concentrations and elemental composition of $\mathrm{PM}_{10} / \mathrm{PM}_{2.5}$ in urban/industrial areas of Kocaeli City, Turkey. Indoor Air 2010;20:112-25. doi: 10.1111/j.1600-0668.2009.00628.x

92. Durukan I, Bektas S, Dogan M, Fittschen U. Analysis of trace elements in airborne particulate matters collected in Ankara, Turkey by TXRF. E3S Web of Conferences 2013;1:20006. doi: 10.1051/e3sconf/20130120006

93. Yatkin S, Bayram A. Source apportionment of PM10 and PM2.5 using positive matrix factorization and chemical mass balance in Izmir, Turkey. Sci Total Environ 2008;390:109-23. doi: 10.1016/j.scitotenv.2007.08.059

94. Koçak M, Mihalopoulos N, Tutsak E, Theodosi C, Zarmpas P, Kalegeri P. PM10 and PM2.5 composition over the Central Black Sea: origin and seasonal variability. Environ Sci Pollut Res 2015;22:18076-92. doi: 10.1007/s11356-015-4928-2

95. Kendall M, Pala K, Ucakli S, Gucer S. Airborne particulate matter $\left(\mathrm{PM}_{2.5}\right.$ and $\left.\mathrm{PM}_{10}\right)$ and associated metals in urban Turkey. Air Qual Atmos Health 2011;4:235-42. doi: 10.1007/s11869010-0129-9

96. Kartal S, Dogan M, Rojas CM, Van Grieken RE. Composition and sources of atmospheric particulate matter at Kayseri, central Turkey. Sci Total Environ 1993;133:83-97. doi: 10.1016/0048-9697 (93)90114-L

97. Gaga EO, Döğeroğlu T, Özden Ö, Ari A, Yay OD, Altuğ H, Akyol N, Örnektekin S, Van Doorn W. Evaluation of air quality by passive and active sampling in an urban city in Turkey: Current status and spatial analysis of air pollution exposure. Environ Sci Pollut Res 2012;19:3579-96. doi: 10.1007/ s11356-012-0924-y

98. Tuygun GT, Altuğ H, Elbir T, Gaga EE. Modeling of air pollutant concentrations in an industrial region of Turkey. Environ Sci Pollut Res 2017;24:8230-41. doi: 10.1007/ s11356-017-8492-9

99. TMMOB Çevre Mühendisleri Odası. Air pollution report 2018 [displayed 5 November 2021]. Available at https://www.cmo. org.tr/genel/bizden_detay.php?kod=100058\&tipi $=91 \&$ sube $=0$

100. Demircigil GÇ, Erdem O, Gaga EO, Altuğ H, Demirel G, Özden Ö, Arı A, Örnektekin S, Döğeroğlu T, van Doorn W, Burgaz S. Cytogenetic biomonitoring of primary school children exposed to air pollutants: Micronuclei analysis of 
buccal epithelial cells. Environ Sci Pollut Res Int 2014;21:1197207. doi: 10.1007/s11356-013-2001-6

101. Çakmak G, Ertürk Arı P, Emerce E, Arı A, Odabaşı M, Schins $\mathrm{R}$, Burgaz S, Gaga EO. Investigation of spatial and temporal variation of particulate matter in vitro genotoxicity and cytotoxicity in relation to the elemental composition. Mutat Res Genet Toxicol Environ Mutagen 2019;842:22-34. doi: 10.1016/j.mrgentox.2019.01.009

102. Kara E, Özdilek HG, Kara EE. Ambient air quality and asthma cases in Niğde, Turkey. Environ Sci Pollut Res 2013;20:422534. doi: 10.1007/s11356-012-1376-0

103. Berktaş BM, Bircan A. Effects of atmospheric sulphur dioxide and particulate matter concentrations on emergency room admissions due to asthma in Ankara. Tuberk Toraks 2003;51:231-8. PMID: 15143399

104. Kargin R, Kargin F, Mutlu H, Emiroglu Y, Pala S, Akcakoyun M, Aung SM, Baran R, Ozdemir N. Long-term exposure to biomass fuel and its relation to systolic and diastolic biventricular performance in addition to obstructive and restrictive lung diseases. Echocardiography 2011;28:52-61. doi: 10.1111/j.1540-8175.2010.01278.x

105. Burroughs Peña MS, Rollins A. Environmental exposures and cardiovascular disease: A challenge for health and development in low- and middle-income countries. Cardiol Clin 2017;35:7186. doi: 10.1016/j.ccl.2016.09.001

106. Hystad P, Larkin A, Rangarajan S, AlHabib KF, Avezum Á, Calik KBT, Chifamba J, Dans A, Diaz R, du Plessis JL, Gupta R, Iqbal R, Khatib R, Kelishadi R, Lanas F, Liu Z, LopezJaramillo P, Nair S, Poirier P, Rahman O, Rosengren A, Swidan H, Tse LA, Wei L, Wielgosz A, Yeates K, Yusoff K, Zatoński T, Burnett R, Yusuf S, Brauer M. Associations of outdoor fine particulate air pollution and cardiovascular disease in 157436 individuals from 21 high-income, middle-income, and lowincome countries (PURE): a prospective cohort study. Lancet Planet Health 2020;4:e235-45. doi: 10.1016/S2542-5196 (20)30103-0

107. Yusuf S, Joseph P, Rangarajan S, Islam S, Mente A, Hystad P, Brauer M, Kutty VR, Gupta R, Wielgosz A, AlHabib KF, Dans A, Lopez-Jaramillo P, Avezum A, Lanas F, Oguz A, Kruger IM, Diaz R, Yusoff K, Mony P, Chifamba J, Yeates K, Kelishadi
R, Yusufali A, Khatib R, Rahman O, Zatonska K, Iqbal R, Wei L, Bo H, Rosengren A, Kaur M, Mohan V, Lear SA, Teo KK, Leong D, O'Donnell M, McKee M, Dagenais G. Modifiable risk factors, cardiovascular disease, and mortality in 155722 individuals from 21 high-income, middle-income, and lowincome countries (PURE): a prospective cohort study. Lancet 2020;395:795-808. doi: 10.1016/S0140-6736 (19)32008-2

108. Arku RE, Brauer M, Ahmed SH, AlHabib KF, Avezum Á, Bo J, Choudhury T, Dans AMl, Gupta R, Iqbal R, Ismail N, Kelishadi R, Khatib R, Koon T, Kumar R, Lanas F, Lear SA, Wei L, Lopez-Jaramillo P, Mohan V, Poirier P, Puoane T, Rangarajan S, Rosengren A, Soman B, Caklili OT, Yang S, Yeates K, Yin L, Yusoff K, Zatoński T, Yusuf S, Hystad P. Long-term exposure to outdoor and household air pollution and blood pressure in the Prospective Urban and Rural Epidemiological (PURE) study. Environ Pollut 2020;262:114197. doi: 10.1016/j.envpol.2020.114197

109. Laden F, Schwartz J, Speizer FE, Dockery DW. Reduction in fine particulate air pollution and mortality. Am J Respir Crit Care Med 2006;173:667-72. doi: 10.1164/rccm.200503$443 \mathrm{OC}$

110. Clancy L, Goodman P, Sinclair H, Dockery DW. Effect of air-pollution control on death rates in Dublin, Ireland: An intervention study. Lancet 2002;360:1210-4. doi: 10.1016/ S0140-6736 (02)11281-5

111. Johnston FH, Hanigan IC, Henderson SB, Morgan GG. Evaluation of interventions to reduce air pollution from biomass smoke on mortality in Launceston, Australia: retrospective analysis of daily mortality, 1994-2007. BMJ 2013;346:e8446. doi: 10.1136/bmj.e8446

112. Lucking AJ, Lundbäck M, Barath SL, Mills NL, Sidhu MK, Langrish JP, Boon NA, Pourazar J, Badimon JJ, GerlofsNijland ME, Cassee FR, Boman C, Donaldson K, Sandstrom T, Newby DE, Blomberg A. Particle traps prevent adverse vascular and prothrombotic effects of diesel engine exhaust inhalation in men. Circulation 2011;123:1721-8. doi: 10.1161/ CIRCULATIONAHA.110.987263

113. Sram RJ. Impact of air pollution on the health of the population in parts of the Czech Republic. Int J Environ Res Public Health 2020;17:6454. doi: 10.3390/ijerph17186454

\section{Izloženost lebdećim česticama - kratki pregled s naglaskom na štetne učinke na srce i krvožilje, djecu i istraživanja provedena u Turskoj}

Za izloženost lebdećim česticama (engl. particulate matter, krat. PM) u zraku iz okoliša već se dugo zna da je povezana sa štetnim djelovanjem na zdravlje. Danas se lebdeće čestice posvuda u svijetu smatraju sistemskim toksikantom koji ne oštećuje samo pluća. Brojna istraživanja, od onih in vitro do epidemioloških, upućuju na raznovrsne izravne i neizravne mehanizme toksičnosti lebdećih čestica koji su povezani s povećanim rizikom od bolesti srca i krvožilja, uključujući upalne odgovore, oksidacijski stres, promjene krvnoga tlaka, autonomnu regulaciju brzine srčanih otkucaja, supresiju endotelne vazodilatacije, trombogenezu, infarkt miokarda i fibrinolizu. Povrh ovih i drugih rizika za zdravlje, u razmatranjima o standardima kakvoće zraka trebaju se uzeti u obzir individualne razlike, stil života i ranjive populacijske skupine poput djece. U Turskoj se onečišćenje zraka u gradovima ističe kao izrazit okolišni problem, pa u ovom preglednom radu posvećujemo pažnju i trenutačnoj situaciji, postojećim istraživanjima i mjerama poduzetima u našoj zemlji.

KLJUČNE RIJEČI: kardiovaskularna toksičnost; kakvoća zraka; praćenje kakvoće zraka; ranjive populacije; zakonska regulativa 